\title{
From Bipolarity to Bipolarity: International Relations Repeating Again
}

\author{
Laris Gaiser • Igor Kovač
}

Published online: 21 November 2012

(C) CEEUN 2012

\begin{abstract}
The end of the Cold War is one of the milestones in the history of international relations. The bipolar world order disappeared; yet, what has replaced it is up for discussion. Several different assumptions of the power structure of the post-Cold War international system have arisen; however, all of them underestimated some factors and overestimated some others. Moreover, there have only been a few attempts to bridge the gap and try to find a consensual narrative between these assumptions. We argue that the power structure of the post-Cold War international system has been quite volatile and has changed in the last two decades several times. The bipolarity of the Cold War was changed into multipolarity due to the lack of political will of the United States to act on the unipolar moment. In 2001, and with a new president in office, the structure changed again. This time the G.W. Bush administration was keen to play the role of a global governor. However, this unipolar moment only lasted until 2006, when the world gradually transformed into a uni-multipolar structure as a result of the relative decline of the US' economic power, and the lack of desired outcomes in the international affairs that were desired and strived for by the US. The economic and financial crisis of 2008 further accelerated the tendencies of reducing the relative power of the US in the international system. Therefore, after 2008 one can observe the world sliding into a non-polar structure. Due to the ungovernable size of the world and the rise of China, we argue that the power structure will become bipolar in the near future once more. Furthermore, we conclude by analysing what would such a structure mean for Euro-Mediterranean region.
\end{abstract}

Keywords Polarity · Global governance · Power structure · USA · China

L. Gaiser $(\bowtie) \cdot$ I. Kovač

Euro-Mediterranean University-EMUNI, Portorož, Slovenia

e-mail: laris.gaiser@emuni.si

I. Kovač

e-mail: igor.kovac@epaneurope.eu 


\section{Introduction}

Henry Kissinger begins his famous book Diplomacy $(1994,17)$ with the following words: "Almost as if according to some natural law, in every century there seems to emerge a country with the power, the will, and the intellectual and moral impetus to shape the entire international system accordance with its own values." The end of the Cold War, a significant milestone in international history, led to a wave of questions related to the power structure of the new international system. Who or what is the power that governs the globe after the fall of the Berlin Wall? The present work addresses this question-what was and is the power structure of the post-Cold War international system.

Various assessments have been made since the fall of the Iron Curtain about the power structure of the post-Cold War international system, among them unipolarity, multipolarity, uni-multipolarity, and non-polarity. This article is devoted to clarify these different theories and find a convergence among them. The motivation behind it is to bring clarity, order and sense into the discourse of power relations after the end of the Cold War. The goal is to bring transparency into the debate, explain why certain theories have been developed at a specific point in the last two decades, and what correlation they have to other ideas.

We will analyse the changing power structure of the international system since the end of the Cold War. We will look at the ideas that were born in the last two and a half decades and how they were applied in reality. The article will be concluded by a prediction about the future balance of power and what will such a structure mean for the Euro-Mediterranean region.

\section{Theories and Concepts of the Power Structure of the Post-Cold War International System}

For more than 20 years, different authors have been writing about the post-Cold War world. As 20 years is quite a long period of time, some authors are referring to the present as the post-post-Cold War world (Friedman 2006). Most authors find September 11, 2001 as a dividing date between post-Cold War world and the post-post-Cold War world (Cossa 2001; Haass 2002).

However, we do not share this view of differentiating between a post-Cold War world and a post-post-Cold War world. Namely, because there was more than one change in the power structure of the international system in the last 20 years and naming them only by adding another 'post' simply does not make sense. Therefore, we will be naming specific time frames of the last two decades according to their power structure.

\section{From Bipolarity to Multipolarity}

At the end of the Cold War there were three ideas present in the academic world about the new nature of the international system. The three ideas were conceptually 
quite different and contradictory to one another, yet, they all found a political manifestation.

First was the idea of a 'new world order'; power would not play a significant role in international relations, the role of a state would vanish, and the main actors of international relations would become international organisations and economic entities. Different names for such concepts were framed, all of them slightly differ from one to another, however their basis is the same-power politics and realism will give way to the cooperation and liberal perception of international relations. This neo-idealist moment (Kegley 1993) is also referred to as 'neo-Wilsonian idealism' (Fukuyama 1992), 'idealpolitik' (Kober 1990), and 'neo-liberalism' (Nye 1988; Grieco 1990).

One of political manifestations of such idea was a speech delivered by the President of the United States of America George Herbert Walker Bush on 11 September (1990), where he pointed to the opportunity to move 'Toward a New World Order'.

Moreover, one of the key advocates of this vision who received the most echoes is Francis Fukuyama, who in 1989 published an article 'The End of History' and then in 1992 his famous book The End of History and the Last Man. In his article he explains (Fukuyama 1989): “/.../ that is, the end point of mankind's ideological evolution and the universalization of Western liberal democracy as the final form of human government. /.../ the victory of liberalism has occurred primarily in the realm of ideas or consciousness and is as yet incomplete in the real or material world. /.../ the death of ideology means the growing 'Common Marketization' of international relations, and the diminution of the likelihood of large-scale conflict between states."

Contrary to 'the optimists', as it is sometimes referred to by the authors of the 'new world order', the second grand idea, or 'the pessimists' arose-the idea of a multipolar world. As the Soviet Union collapsed, some authors argued that due to the rise of Japan, the EU and other actors in international affairs, the world would become multipolar. Paul Kennedy (1989, 438-439) introduced the term 'Imperial Overstretch' with which he portrayed the nature of the empire to extend itself beyond its ability to maintain and control its military and economic commitments. This is what, he argued, is happening to the USA.

An example of a political manifestation of this vision of the post Cold War world is the quote from Paul Tsongas, the late US Senator from Massachusetts, who at the 1992 Democratic Convention said: "The Cold War is over; Japan won" (Dowd 1992).

One of the key figures of pessimistic multipolar vision was John Mearsheimer (1990), who argued that this reversion from bipolarity to multipolarity will likely have disastrous consequences for Great Power peace. He draws a parallel between the future of the Great Powers and the experiences of Europe in the early twentieth century; and criticized optimistic arguments that the future will be peaceful due to the high costs of modern war, the existence of many democracies, and learning - a socialisation process (Mearsheimer 1990).

Where the optimists see the end of the Cold War as the negation of the international system's war-like past, the pessimists see it as the return of the past. 
The third grand idea is the idea of a unipolar world. Whereas the second big idea stresses the balance of power, the third stresses hegemony. As the Soviet Union collapsed there was only one superpower left-the US. Thus, mathematically it would be logical that the world would be transformed from a bipolar one into a unipolar one. Some Authors proclaimed the post-Cold War as Pax Americana (Muravchik 1991), and others as American Hegemony (Layne and Benjamin 1993).

An interesting political manifestation of this vision occurred in March 1992 in a leaked initial draft of the Pentagon's Defence Planning Guidance (DPG) for Fiscal Years 1994-99. It was written (Tyler 1992): "We must account sufficiently for the interests of the large industrial nations to discourage them from challenging our leadership or seeking to overturn the established political or economic order and that we must maintain the mechanisms for deterring potential competitors from even aspiring to a larger regional or global role." The initial draft of the DPG was controversial, and in a subsequent draft the language referring to the goal of preserving unipolarity was deleted.

The main protagonist of such an idea was Charles Krauthammer, who in 1990 wrote an article titled 'The Unipolar Moment'. Krauthammer (1990/1991) predicted that a unipolar moment will last approximately a decade before an unstable multipolar world will emerge.

Looking back, one can conclude that the three different ideas were partially proven right; yet, they are partially insufficient as well. All of them tend to overestimate their arguments and oversee other relevant factors.

As attractive as it sounds, Fukuyama's thesis did not fully fulfil itself. It had a big momentum in the first Clinton administration as well as in G.H.W. Bush administration. However, none of them embraced it completely and thus we are left with two remaining big ideas.

The US was faced with the question 'what to do with its primacy' (Art 1991)? The US did not find an answer to this question. We argue that the end of the Cold War surprised the US and therefore they did not have the answer to those unexpected challenges. Therefore, the US did not play the role of the one remaining superpower (Rice 2000, 45). The US needed time to fully understand the new situation in international relations (Kissinger 1994, 809). Due to the lack of the US exercise of its unique role in the early 1990s, the world was not unipolar, as it would have been if the US had exercised its power potential, but rather it was multipolar.

The administration of G.H.W. Bush stressed that foreign policy is not their priority (Heffernan 2005, 570). However, it made quite an impact in international affairs. In 1989 it intervened in Panama (Operation Just Cause), in 1991 Bush and Gorbachev signed a Strategic Arms Reduction Treaty-START I (negotiations lasted 9 years), and most importantly the US begun the Gulf War in January 1991. Despite these actions the G.H.W. Bush administration did not develop a new foreign policy vision and strategy for a new situation in international affairs in order to implement the idea of unipolarity. Furthermore, neither did the first Clinton administration (Stein and Lobell 1997, 121). Therefore, 1990s made the unipolar vision moot (Ikenberry 2002, 50), which is why Layne $(1993,5)$ wrote that the United States has not imposed a universal monarchy. 
Another argument as to why the US never fully seized the unipolar moment in the early 90' and thus making the world multipolar, was the 1992 elections. In the US elections the interior topics are always in the forefront. Thus, the G.H.W. Bush administration had to focus on internal political issues, and therefore foreign policy did not get the attention, time and energy it needed.

Consequently, the power structure of the international system changed from bipolar (in the Cold War) to multipolar (post-Cold War). Even if one accepts the argument of the Gulf war as a sign of unipolarity, the US, still, did not follow up on that action. Such an argument does not satisfy us. Yet, if we nonetheless take it into consideration, then the unipolar moment was really just a moment. It was so brief that it lasted only a few months in the transition from bipolarity to multipolarity, and did not have a relevant impact on the changing of the power structure of the international system. As we will show, the unipolar momentum of the US came to fruition 10 years later.

Although all three big ideas of the post-Cold War international system that were present at the time of the collapse of the Eastern bloc received political attention and experienced political manifestations, it was the pessimistic idea of multipolarity that prevailed in the 1990s.

\section{From Multipolarity to Unipolarity}

The priorities of the first Clinton administration were of economic nature-there was economic growth and inflation together with decreased unemployment. However, the Clinton administration continued to be passive in the international arena. Ikenberry $(1996,387)$ wrote: "If there is one consistent complaint in politics around the world today, it is about the absence of leadership-local, national, global." The US did not take the position of the world hegemonic power, what plunged the world into a multipolar chaos-(civil) wars, genocides, lack of global governance, and the rules of the new international affairs were not set. Mearsheimer is right (2001, 58-59) when he compares such behaviour to the inter-war period, where the US retreated into isolationism. The mistake was not repeated after the Second World War; however it was repeated after the Cold War.

Clinton's 'trade first' policy-during his two administration, over 300 of trade agreements were ratified and implemented (Clinton 2000)_contradicted numerous security and other interests of the US (Nau 1995, 3-6). Such a policy focused on exports, but overlooked security and political instabilities of the markets where the exports went to (Nau 1995, 3-6). Therefore the US did not confront the main challenges of the post-Cold War world (the rise of China, what to do with Russia, growing instability of some regions) (Nau 1995, 3-6). According to the 'Clinton doctrine' the US does not need allies because in the economic markets one does not know who is an ally and who is a competitor; hence the US foreign policy was reduced to power-economics (Nau 1995, 16). Mastanduno $(1997,52)$ referred to such a policy as 'economic hardball' and 'security softball'.

Even as Clinton laid out his extremely ambitious foreign policy goals (1993 Oslo agreement, and 1994 agreement with North Korea, Bosnia and Kosovo), he proved unwilling to support them with the necessary means (Dueck 2003/2004, 6). 
In particular, he proved reluctant to support these initiatives with the requisite amount of military force (Somalia, Haiti, Bosnia, or Kosovo). In one case after another of humanitarian intervention, a pattern emerged: the Clinton administration would stake out an assertive and idealistic public position, and then refuse to act on its rhetoric in a meaningful way (Dueck 2003/2004, 6).

By the end of Clinton's first term it was clear that to bring order in the international system, the US needed to start implementing its hegemonic potential. Alongside the already mentioned genocides, Islamic fundamentalism were growing in Central Asia (Kabul was seized in 1996), US embassies in Kenya and Tanzania were attacked, China's economic rise and its penetration into different world regions with rich energy resources marked the mid 1990s. All of these were additional catalysts for the change in the US behaviour in international relations. In December 1995 the Dayton accords were signed in Paris that ended the war in the Balkans. However, the violence continued in 1998 in Kosovo, yet this time the second Clinton administration was determined and in 1999 NATO intervened without the authorization of the United Nations Security Council and in the same year NATO also admitted three new members to NATO.

The second Clinton administration continued with the 'trade first' foreign policy that led to the inclusion of China into the World Trade Organization (WTO), without putting pressure on it to follow the WTO rules and principles (Nayar 2005, 203). The idea behind that was if China is included into the global community, democratic changes can be triggered. The US followed an idea that no authoritarian regime can stand a certain level of economic development-\$3,000 GDP per capita (Gunde 2004). The case of China casts doubts on it, since Chinese GDP is already more than $\$ 4,000$ per capita (according to World Bank in 2008 Chinese GDP per capita exceeded \$3,000). Furthermore, China does not respect commitments of certain international organisations (WTO) (Hughes 2005, 94). Clinton's policy towards China did not provide the results it wanted.

However, a slight change from Clinton's first term was noticeable in the activity of the US. The second Clinton administration became more assertive and began to follow the unipolar momentum. It also changed its rhetoric. Madeleine Albright, in 1998 said that: "we are the indispensable nation. We stand tall and we see further than other countries into the future, and we see the danger here to all of us (Albright 1998)." The most obvious fact for such a statement is the above mentioned 1999 intervention in Kosovo. Unlike the Gulf War and Somalia, this intervention did not have the mandate of the UN Security Council.

Yet, we argue that the NATO intervention in 1999 is not as much a sign of unipolarity, as it is the final blow to the 'new world order' ideology that was present in the political arena for a decade. 1999 clearly marks the 'return of the history and the end of dreams' as Robert Kagan's 2008 book is titled. Our main argument for it is that US changed its behaviour; however, it still lacked a coherent vision of its actions. Namely, unipolarity by definition needs a force to maintain and govern it according to its vision.

The multipolar world of the 1990s that was a result of the inactivity of the US began to take a different shape. The idea of unipolarity was never implemented and manifested fully in a foreign policy vision. After 1999, and with the new president 
George Walker Bush, such a vision took shape and form. The world thus became unipolar in 2001 with the G.W. Bush administration. Upon taking office in 2001, the G.W. Bush administration initiated some significant changes in American grand strategy: it emphasised military preparedness, great-power politics, and concrete national interests (Dueck 2004, 523). Immediately after the invasion of Afghanistan and Iraq some authors even argued that such a concentration of power was never present in world history (Brooks and Wohlforth 2002).

As one can observe, the reasons for changing polarity since the end of the Cold War were not material, but rather political. It was political decisions that produced multipolarity in the 1990s, and it was political decisions that made the world unipolar in 2001.

\section{From Unipolarity to Uni-Multipolarity}

The G.W. Bush Administration came into office confident of the US supremacy, especially military, and was determined to preserve it (Friedberg 2009, 30). This administration had a vision of a new foreign policy for the US. It was manifested in an article written by Condoleezza Rice in 2000 published in Foreign Affairs. The implementation of a new strategy may be seen in the opening of new basis in the former Soviet geopolitical space (Bulgaria, Romania, Poland, Lithuania, Georgia, Uzbekistan, Kazakhstan, Kyrgyzstan) (Paolini 2004, 123-138), withdrawal from the Anti-ballistic Missile Treaty (due to the building of missile defences against the rogue states), the US using its veto power on the verification protocol Biological Weapons Convention, the US had stopped sending Russia aid for reduction of nuclear arsenal as stated in Cooperative Threat Reduction Program, START I and START II were jointly replaced by Bush and Putin with an informal Strategic Offensive Reductions Treaty (SORT) agreement (Raščan 2005, 97), transforming the US armed forces to prepare them for twenty-first century warfare against future advanced opponents (Rice 2000), refusing to sign the Kyoto Protocol, and refused to ratify the Rome Statute of the International Criminal Court. Ikenberry (2002) saw this new USA foreign policy strategy as neo-imperialistic.

Moreover, the key feature of the new concept is coping with rogue regimes, and managing Beijing and Moscow (Rice 2000). Early on the G.W. Bush administration saw China and Russia as strategic challenges. This view changed after 11 September 2001 and the wars in Afghanistan and Iraq. In many ways 11 September made the world even more unipolar, since the US showed its military potential- the conquest of Afghanistan and the overthrow of the Taliban took about 2 months from a standing start, with virtually no advance preparation; despite warnings of a quagmire like the one the Soviets had fallen into in the 1980s (Friedberg 2009, 30). It showed the power and unipolar resolve of the US. Brooks and Wohlforth wrote (2002, 21): "If today's American primacy does not constitute unipolarity, then nothing ever will." However, 11 September does not represent a structural change in the international system. It has intensified the unipolar structure and brought changes to the US foreign policy, but the international system has not been systematically changed by it. 
On the other hand, the acts that followed 11 September 2001 revealed a vulnerability of the super power. Furthermore, after the attacks, the US foreign policy was altered. China and Russia were not perceived as strategic challenges anymore, but as strategic allies. The War on Terror demanded the adaptation of the 2000 strategy. The National Security Strategy of the United States in 2002 had conceptualised such a change and some authors named it the Bush doctrine (Krauthammer 2004). This new strategy made it possible for states that violated basic human rights, but were geopolitically significant (Uzbekistan and Sudan) to become strategic partners with the US (Raščan 2005, 98). Furthermore, the Pentagon also adopted a new doctrine-the so-called 1-4-2-1. It required a force able to defend the US homeland, operate in and from four forward regions, swiftly and simultaneously defeat two regional adversaries, and achieve a more decisive and enduring result such as regime change in one of those regions (Owens 2006, 315). These new strategies had its negative effects on the US as well, especially for its soft power. In the eyes of many countries it is becoming the rogue superpower (Huntington 1999, 42).

Still in 2002 and 2003 the US supremacy was not disputed. Krauthammer (2002, 17) reframed the unipolar moment into a unipolar era. Even more, Kennedy (2002), who predicted the fall of the US in the late 1980s, admitted his mistake.

Indeed, the ideas of multipolarity and declinism were at the best only in the back seat. However, the US did not establish an empire. Krauthammer's definition of unipolarity, as a system with only one pole, made sense in the immediate wake of the Cold War, but a decade later what increasingly seemed salient was less the absence of a peer rival than the persistence of a number of problems in the world that Washington could not dispose of by itself (Brooks and Wohlforth 2002, 20-21).

The US economy started to show its weaknesses. Furthermore, the military interventions could not stabilise Afghanistan and Iraq. Military power was not 'the almighty' which can solve all challenges. The US learned the hard way, as Jervis $(2003,86)$ put it, it is harder to build than to destroy. The G.W. Bush administration noticed this and for the second time readjusted its foreign policy strategy outlined in The National Security Strategy of The United States of America 2006. Condoleezza Rice also presented foreign 'policy vision 3.0' in her 2008 article in Foreign Affairs, where she stressed the importance of cooperating with China and Russia (Rice 2008, 3-6). By the end of 2006, even Krauthammer was forced to conclude that the United States was 'past the apogee' of its unprecedented power (Krauthammer 2006). Nye (2002) pointed out that the structural power and the different power factors of the US, although it is the biggest power, cannot be controlled. The term unipolarity is misleading because it exaggerates the degree to which the US is able to get the results it wants in some dimensions of world politics (Nye 2002, 38-39). As Friedberg $(2009,32)$ noted: "Some observers made the classic Political Science 101 mistake of equating 'power as control over resources' with 'power as control over outcomes'. Just because the United States has the largest economy and the most powerful military does not mean that it can get everyone to do everything it wants all of the time." The unipolar moment was nearly over. Was a new era of multipolarity at hand? 
Our answer is-not really. At that point the world was far from multipolarity and much closer to the concept of Huntington's uni-multipolarity (Huntington 1999, 35-36): "There is now only one superpower. But that does not mean that the world is unipolar. A unipolar system would have one superpower, no significant major powers, and many minor powers. A multipolar system has several major powers of comparable strength that cooperate and compete with each other in shifting patterns. Contemporary international politics does not fit any of these three models. It is instead a strange hybrid, a uni-multipolar system with one superpower and several major powers."

As explained for the first three grand theories of the power structure of the post-Cold War international system-they were all politically and academically relevant, still they were all inadequate-and the same goes for Huntington's uni-multipolarity.

The concept that Huntington presented became a reality after 2006, not in 1999 when he wrote it. The US is the world's biggest power; however, in 2006 it could not keep the world in a state of unipolarity. Furthermore, other major powers could not yet counter-balance the power of the US, so the world was not multipolar. Other major powers still need the US on board if they wish to do something substantial in the world. The same goes for the US, which needs a number of major powers in order to do something substantial in the world. The US cannot 'go it alone' and others cannot do anything without the US. Although correct in 2006, there is a time gap of 7 years to the time when Huntington wrote his article. For the volatile time of the post-Cold War international system this is quite substantial. Moreover, after 1999 the US was able, albeit briefly, to create a unipolarity. We argue that Huntington underestimated the role of the agency, and overestimated the power of other players in the world.

The name uni-multipolarity may indicate that some of the aspects of the international system are unipolar, and others are multipolar. Such an interpretation may be found in Nye (2010) analyses.

As demonstrated, the first G.W. Bush administration implemented the idea of unipolarity. Therefore, the structure of the international system went from multipolar to unipolar. With the US entangled up in Afghanistan and Iraq, its economy slowing down, the rise of other actors in the international arena, unreached goals, and dealing with uncontrollable outcomes, the world has become unimultipolar. Many expected that such a system will be transformed into a multipolar one. However, we will argue differently.

\section{Contemporary Shift from Uni-Multipolarity to Non-Polarity}

Through the military entanglement in Afghanistan and Iraq, the new Security strategy of the US (2006) and the economic situation in the US, Richard Haass (2008) observed an increasing distributed power, rather than a concentrated power in the world. Thus, he defined non-polarity as (Haass 2008): "The principal characteristic of twenty-first-century international relations is turning out to be nonpolarity: a world dominated not by one or two or even several states but rather by dozens of actors possessing and exercising various kinds of power. /.../ In contrast 
to multipolarity-which involves several distinct poles or concentrations of power-a non-polar international system is characterized by numerous centres with meaningful power." Haass (2008) explains that today's world differs in a fundamental way from one of classic multipolarity as there are many more power centres, and quite a few of these poles are not nation-states. Power is now found in many hands and in many places (Haass 2008). Haass builds on the narrative of Suzan Strange, who wrote that the power is shifting sideways from states to markets and other non-state actors (Strange 1996, 189).

It seems that especially with the economic crisis that began in 2008, Haass' concept of non-polarity is a very convenient way to describe the power distribution in the world. Many observers have interpreted the 2008 global financial crisis as the beginning of the American decline (Nye 2010), especially due to the bankruptcy of Lehman Brothers (15 September 2008). Indeed, the latter has had a much bigger impact on the international system then 11 September 2001. 15 September has structural consequences, which was not the case after the 11 September. Such a perception may be further strengthened by recalling Krauthammer's thesis of a unipolar moment. In his article he wrote: "An American collapse to second-rank status will be not for foreign but for domestic reasons. America's low savings rate, poor educational system, stagnant productivity, declining work habits, rising demand for welfare state entitlements and new taste for ecological luxuries have nothing at all to do with engagement in Europe, Central America or the Middle East. Over the last 30 years, while taxes remained almost fixed (rising from 18.3 to $19.6 \%$ ) and defence spending declined, domestic entitlements nearly doubled (Krauthammer 1990/1991, 26)."

The economic crisis not only hurt the US economic and military power, but it also hurt the US soft power. Wall Street's inability to police itself, showed devastating consequences for the rest of the world, and could also diminish America's soft power by discrediting its model of liberal capitalism (Friedberg, 2009, 35). Furthermore, the US soft power had similar effects as seen by the reluctance to close Guantanamo prison, incidents in Abu Ghraib and other indiscretions by the US soldiers (urination on corpses, tarring the Quran), and the drone war.

Yet, we argue that this new wave of American declinism suffers from the same flaws as previous ones-overestimation of particular facts. Indeed the rise of the rest' has had its consequences for power distribution-the relative power of the US is in decline, nevertheless, as it was true in the late 1980s, it would be unwise to bet against the resilience and adaptability of the American system (Friedberg 2009, 35). American soft-economic power has by no means declined-/.../ for the moment, the dollar has not lost its lustre and has actually become more attractive in light of recent uncertainties (Eichengreen 2009). It seemed that with the Obama administration, the US would buffer the negative consequences of the military actions on the US soft power. Although receiving a Nobel Peace Prize, the Obama administration continued the Bush practices regarding the War on Terror. Not only had Guantanamo not been closed as Obama had promised, but distasteful incidents by soldiers continued, the drone war escalated, and the US assassinated not only terrorists in foreign countries, but also its own citizens in foreign countries that were 
considered as a threat to its security-without trial. Still, other aspects of the US soft power remained unshaken-popular culture, education, language, tourist destination, and the image of a 'country where dreams are possible'.

However, some other authors made completely different conclusions than Haass. In his article 'The Default Power' which was published during the economic crisis in 2009 by Foreign Affairs, Josef Joffe, explains that even with the economic crisis, the US economic predominance is not threatened. He writes: "In all instances of declinism, economic failure serves as Exhibit A. But current figures show the US economy to be worth $\$ 14.3$ trillion, three times as much as the world's secondbiggest economy, Japan's, and only slightly less than the economies of its four nearest competitors combined-Japan, China, Germany, and France. Today, there is only one challenge to the dominance of the US economy: the European Union's aggregate GDP of $\$ 18$ trillion. But the more appropriate comparison may be with the 16-member Euro-zone, which has a common monetary policy and a rudimentary common fiscal policy - and a collective GDP of $\$ 13.5$ trillion. The US also comes out ahead among major powers in terms of per capita income, with $\$ 47,000$ per inhabitant. It is followed by France and Germany (both in the $\$ 44,000$ range) (Joffe 2009)." Additionally, the US military power is unreachable. In 2008, the US spent $\$ 607$ billion on its military, representing almost half of the world's total military spending (Joffe 2009). The next nine states spent a combined total of $\$ 476$ billion, and the presumptive challengers to the US military supremacy-China, India, Japan, and Russia-together devoted only $\$ 219$ billion to their militaries (Joffe 2009). Similar can be said about the 'soft power' of the US. Of the world's top 20 universities, all but three are in the US; of the top 50, all but 11 are located in the US (Joffe 2009). By contrast, India's two best universities are tucked away in the 300-400 tier. China does a bit better as, its top three-Nanjing University, Peking University, and Shanghai University - are in the 200-300 group of the world's 500 best universities (Joffe 2009).

Joffe analysis provides arguments that oppose Haass' statement of non-polarity. Haass focuses on the analyses of the outcomes, and Joffe on the power factors. There is a big gap between them. Again, both are relevant, and yet inadequate at the same time. Haass is right when he stresses the relevance of non-state actors, nevertheless, is their influence and impact so vast that it makes the world non-polar? We disagree. On the other hand, Joffe stresses the power factors and capabilities; still he overlooks the outcome and results of implementing that power. Both of the authors overlook an important aspect of analysis.

This anomaly was tackled by Nye. He builds on Huntington's thesis about unimultipolarity and said: "Power today is distributed in a pattern that resembles a complex three-dimensional chess game. On the top chessboard, military power is largely unipolar, and the US is likely to retain primacy for quite some time. On the middle chessboard, economic power has been multipolar for more than a decade, with the US, Europe, Japan, and China as the major players and others gaining in importance. The bottom chessboard is the realm of transnational relations. It includes non-state actors as diverse as bankers who electronically transfer funds, terrorists who traffic weapons, hackers who threaten cyber-security, and challenges such as pandemics and climate change. On this bottom board, power is widely 
diffused, and it makes no sense to speak of unipolarity, multipolarity, or hegemony. The word 'decline' mixes up two different dimensions: absolute decline, in the sense of decay, and relative decline, in which the power resources of other states grow or are used more effectively (Nye 2010)."

We find Nys's adoption of Huntington's uni-multipolarity very convincing. However, if we agree with the levels of the game, we disagree with the nature of the second chess board-economic. Multipolarity means that power is exercised by a multiple actors. Yet, since 2008 economic crisis this level was lacking just thatexercising power and governance. Thus, since 2008 also the second economic level of great power chess game moved to non-polarity. Therefore we conclude that contemporary international system is in an ongoing slide towards non-polarity.

It is highly unlikely, due to the overwhelming advantage that the US has in the military power relations, that the international system as a whole will become nonpolar. Thus, a just question remains to be answered-where are we going from here?

\section{Conclusion-Towards a New Bipolarity?}

In such a described situation, one can easy make an argument that the contemporary international system lacks a governor as never before. Never before has the indispensable need for architecture of international governance been so strongly felt (Dominese 2009, 230). Bremmer and Roubini (2011) named this world G-0. Washington is too weak to drive the 'Washington consensus' alone, however a 'Beijing consensus' cannot be developed (Bremmer and Roubini 2011). Therefore, we argue that in the future international community will witness a struggle for the position of global governor.

As it can be deducted from the previous chapter, we believe that the contemporary globalized world is too big to be governed by a single power. Therefore, the future fight for global governance will be an antagonism between different alliances. Yet, alliances will be only made among the actors that share similar vision of the global order. Again, as in the Cold War, an ideological rivalry of a few power centres may be expected.

A very compelling case was made in 2007 by Carlo Pelanda in his book Grand Alliance, where he argues that a new bipolar strife is inevitable. He argues that the future bipolar fight for global governance will be between the two different concepts-autocratic and democratic capitalism. The main protagonist of both camps would be in his scenario the US and China. He continues that in order for democratic capitalism to prevail and become the global governor, a grand alliance between the US, EU and Russia has to be forged.

If the US begins to perceive China as a competitor, it will focus its foreign policy resources towards Pacific and Asia. To be specific, with the decision of the Pentagon to shift $60 \%$ of its navy to Pacific, the geopolitical shift from Atlantic to Pacific already began to take political shape. Consequently, the EU and the Mediterranean region will be shoved to the geopolitical brink. This will be the first time in history that Europe will not be in the geopolitical centre of global politics and governance. 
Furthermore, focusing exclusively on China, and not taking into consideration the vision of grand alliance will open a critical blind side for the US.

Namely, as in the Cold War when the Euro-Mediterranean was one of the key regions for the stability between the two blocks, the Euro-Mediterranean region is re-emerging today as a crucial shatterbelt of the world. EU debt crisis, instability of Northern Africa, Arab revolutions, the new alliance between Israel and Saudi Arabia to contain Iran, the ongoing geopolitical challenges of the Middle East, and the Chinese penetration into the region, should remind us that the struggle for global governance cannot be simply played out on the Pacific. Thus, if the US wishes for a grand alliance, then they should focus also on Euro-Mediterranean.

The dangers of marginalisation of Euro-Mediterranean were well presented by Carlo Jean in his 2007 book Geopolitica del Caos. If the US really desires that democratic capitalism will become the global governor, then they should pay attention what is going on in the backyard of their crucially-EU. The US should newly engage actively in the Euro-Mediterranean region to make it prosperous and stable. In the future a Euro-Mediterranean transatlantic approach would be needed considering it as a geopolitical macro-region.

\section{References}

Albright M (1998) Transcript: Albright interview on NBC-TV. http://www.fas.org/news/iraq/1998/02/19/ 98021907_tpo.html. Accessed 31 May, 2012

Art R (1991) Defensible defense: America's grand strategy after the Cold War. Int Secur 4:5-53

Bremmer I, Roubini N (2011) A G-zero world, the new economic club will produce conflict, not cooperation. Foreign Affairs. http://www.foreignaffairs.com/articles/67339/ian-bremmer-and-nourielroubini/a-g-zero-world. Accessed 31 May, 2012

Brooks S, Wohlforth W (2002) American primacy in perspective. Foreign Affairs 4:20-33

Bush GHW (1990) Toward a new world order. http://bushlibrary.tamu.edu/research/public_papers.php? id=2217\&year=1990\&month=9. Accessed 29 May, 2012

Clinton WJB (2000) Remarks by the president 'A Foreign Policy for the Global age' address to the University of Nebraska. http://www.fas.org/news/usa/2000/usa-001208zws.htm. Accessed 11 June, 2012

Cossa R (2001) Toward a post post-Cold War world. PacNet 41. http://csis.org/files/media/csis/pubs/ pac0141.pdf. Accessed 29 May, 2012

Dominese G (2009) Global governance and innovation 2020: how to govern the complexities of the future. Trans Stud Rev 2:229-232

Dowd M (1992) The 1992 campaign: campaign memo; voters want candidates to take a reality check. The New York Times. http://www.nytimes.com/1992/02/17/us/the-1992-campaign-campaignmemo-voters-want-candidates-to-take-a-reality-check.html?src=pm. Accessed 29 May, 2012

Dueck C (2003/2004) Hegemony on the cheap: liberal internationalism from Wilson to Bush. World Policy J 4:1-11

Dueck C (2004) Ideas and alternatives in American grand strategy, 2000-2004. Rev Int Stud 4:511-535

Eichengreen B (2009) The dollar dilemma. Foreign Affairs. http://www.foreignaffairs.com/articles/ 65241/barry-eichengreen/the-dollar-dilemma. Accessed 31 May, 2012

Friedberg AL (2009) Same old songs, what the declinists (and triumphalists) miss. The American Interest. http://www.the-american-interest.com/article.cfm?piece=715. Accessed 31 May, 2012

Friedman TL (2006) The post-post-Cold war. The New York Times. http://www.nytimes.com/2006/ 05/10/opinion/10friedman.html. Accessed 29 May, 2012

Fukuyama F (1989) The end of history? The National Interest. http://www.wesjones.com/eoh.htm. Accessed 29 May, 2012 
Fukuyama F (1992) The end of history and the last man. Free Press, New York

Grieco JM (1990) Cooperation among nations: Europe, America, and non-tariff barriers to trade. Cornell University Press, Ithaca

Gunde R (2004) China's democratic future: how it will happen and where it will lead. http://www.international.ucla.edu/article.asp?parentid=8710. Accessed 31 May, 2012

Haass RN (2002) Defining US foreign policy in a post-post-Cold War world. DISAM J 1-2:30-37

Haass RN (2008) The age of nonpolarity, what will follow US dominance? Foreign Affairs. http://www.foreignaffairs.com/articles/63397/richard-n-haass/the-age-of-nonpolarity. Accessed 31 May, 2012

Heffernan M (2005) The end of Atlanticism: Habermas, Derrida and the meaning of Europe in the twenty-first century. Geopolitics 3:570-574

Hughes NC (2005) A trade war with China? Foreign Affairs 4:94-106

Huntington SP (1999) The lonely superpower. Foreign Affairs 2:35-49

Ikenberry J (1996) The future of international leadership. Political Sci Q 3:385-402

Ikenberry J (2002) America's imperial ambition. Foreign Affairs 5:44-60

Jean C (2007) Geopolitica del Caos. Attualità e prospettive, Franco Angeli

Jervis R (2003) The compulsive empire. Foreign Policy 137:82-87

Joffe J (2009) The default power, the false prophecy of America's decline. Foreign Affairs. http://www.foreignaffairs.com/articles/65225/josef-joffe/the-default-power. Accessed 1 June, 2012

Kagan R (2008) The return of history and the end of dreams. Vintage Books, New York

Kegley CW (1993) The neoidealist moment in international studies? Realist myths and the new international realities. Int Stud Q 2:131-146

Kennedy P (1989) The rise and fall of the great powers: economic change and military conflict from 1500 to 2000. Vintage Books, New York

Kennedy P (2002) The Eagle has landed. Financial Times. http://www.ratical.org/ratville/JFK/JohnJudge/ linkscopy/EagleLand.html. Accessed 31, May 2012

Kissinger H (1994) Diplomacy. Simon \& Schuster Paperbacks, New York

Kober S (1990) Idealpolitik. Foreign Policy 79:3-24

Krauthammer C (1990/1991) The unipolar moment. Foreign Affairs 1:23-33

Krauthammer C (2002) The unipolar moment revisited. Natl Interest 70:5-17

Krauthammer C (2004) Democratic realism: an American foreign policy for a unipolar world. American Enterprise Institute Press, Washington

Krauthammer C (2006) Past the apogee: America under pressure. Keynote Address at the Foreign Policy Research Institute Annual Dinner. http://www.fpri.org/enotes/20061213.krauthammer.pastapogee. html. Accessed 31 May, 2012

Layne C (1993) The unipolar illusion: why new great powers will rise. Int Secur 4:5-51

Layne C, Benjamin S (1993) American hegemony: without an enemy. Foreign Policy 92:5-23

Mastanduno M (1997) Preserving the unipolar moment: realist theories and US grand strategy after the Cold War. Int Secur 4:49-88

Mearsheimer J (1990) Back to the future: instability in Europe after the cold war. Int Secur 4:5-56

Mearsheimer J (2001) The tragedy of great power politics. Norton, New York

Muravchik J (1991) At last, Pax Americana. The New York Times. http://www.nytimes.com/1991/ 01/24/opinion/at-last-pax-americana.html. Accessed 29 May, 2012

Nau HR (1995) Trade and security: U.S. policies at cross-purposes. American Enterprise Institute, Washington

Nayar BR (2005) The geopolitics of globalization: the consequences for development. Oxford University Press, Oxford

Nye J (1988) Neorealism and neoliberalism. World Politics 2:235-251

Nye J (2002) The paradox of American power: why the world's only superpower can't go it alone. Oxford University Press, New York

Nye J (2010) The future of American power, dominance and decline in perspective. Foreign Affairs. http:// www.foreignaffairs.com/articles/66796/joseph-s-nye-jr/the-future-of-american-power. Accessed 31 May, 2012

Owens MT (2006) A balanced force structure to achieve a liberal world order. Orbis 2:307-325

Paolini M (2004) La NATO dell'esto. Limes 6:123-138

Pelanda C (2007) The grand alliance. The global integration of democracies. Franco Angeli, Milano

Raščan S (2005) Spremembe varnostne politike ZDA po 11. septembru 2001. Fakulteta za družbene vede, Ljubljana 
Rice C (2000) Promoting national interest. Foreign Affairs 1:45-62

Rice C (2008) Rethinking national interest. Foreign Affairs 4:2-26

Stein A, Lobell S (1997) Geostructuralism and international politics: the end of the Cold War and the regionalization of international security. In: Lake D, Patrick M (eds) Regional orders: building security in a new world. Pennsylvania State University Press, University Park, pp 101-122

Strange S (1996) The retreat of the state: the diffusion of power in the world economy. Cambridge University Press, Cambridge

The National Security Strategy of the United States of America (2002) http://merln.ndu.edu/whitepapers/ USnss2002.pdf. Accessed 31 May, 2012

The National Security Strategy of the United States of America (2006) http://www.comw.org/qdr/ fulltext/nss2006.pdf. Accessed 31 May, 2012

Tyler PE (1992) Pentagon imagines new enemies to fight in post-Cold-War era. The New York Times. http://www.nytimes.com/1992/02/17/world/pentagon-imagines-new-enemies-to-fight-in-post-coldwar-era.html?pagewanted=all\&src=pm. Accessed 29 May, 2012 